\title{
Strategic Alliances or M \& A as the Road to Innovation for Pharmaceutical Companies?
}

\section{Lars Schweizer*}

Goethe University Frankfurt, UBS-Endowed Chair for Strategic Management, Grueneburgplatz 1, 60322 Frankfurt am Main, Germany

Biotechnology and pharmaceutical are one of the strongest growing industries of the twenty-first century. Since the inception of Genentech - which is often referred to as the first modern biotechnology firm - in 1976, many thousands of new biotechnology ventures have been founded, and some of these ventures have been extraordinarily successful [1]. For example, Genentech's market capitalization was $\$ 100$ billion in 2012, and the firm employed more than 11,000 people.

There is a steady increase in the number and scope of strategic alliances between biotechnology and pharmaceutical companies [2], because in an increasingly cost-conscious environment pharmaceutical companies need innovative products to achieve premium pricing and gain market share. Biotechnology companies continue to invest heavily in research and development and, by this, serve as a source of products, technologies and know-how for pharmaceutical companies. Besides M\&A (Mergers and acquisitions), strategic alliances are considered as a very important and widespread possibility in order to gain access to the knowledge incorporated in biotechnology companies [1,3]. Powell et al. [4] points out that the core capabilities of organizations are derived from knowledge-seeking and knowledge creation.

It becomes obvious, that pharmaceutical companies need to follow different tracks in order to survive in a highly-dynamic and innovationdriven environment. Although there is a lot of literature about either M\&A activities between pharmaceutical or biotechnology companies or about strategic alliances between these companies, there is no study that tries to link and compare these two perspectives and that analyses why and how pharmaceutical companies go for alliances in some cases and prefer M\&A in others. There is a clear need to close that gap by providing some insights about (1) the strategic decision-making process of what option to choose under what circumstances and (2) of what gains pharmaceutical companies can expect from collaborations with other pharmaceutical companies, on the one hand, and collaboration with biotechnology companies, on the other hand.

The research design of such a study is best described in a $2 \times 2$ matrix (Figure 1) determined by pharmaceutical and biotechnology

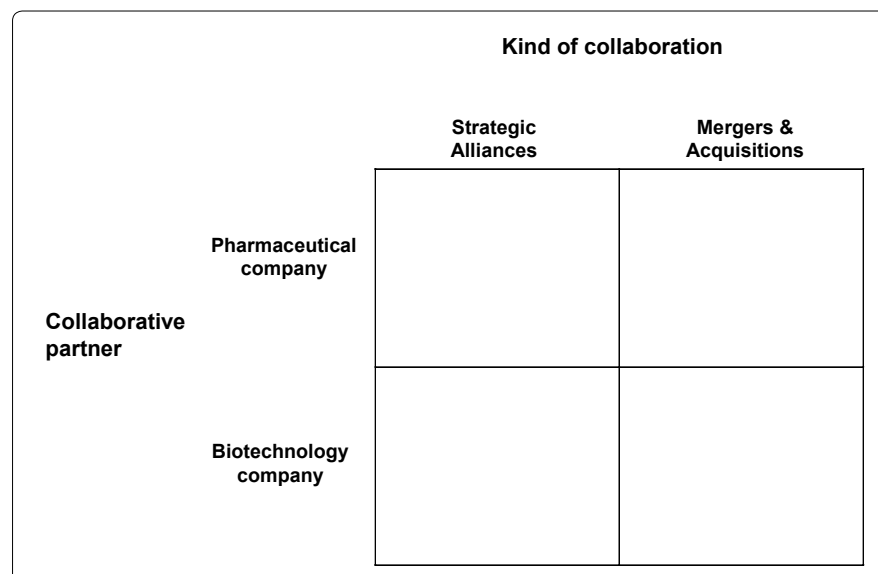

Figure 1: Research framework. companies as potential partners on one axis and by strategic alliances or acquisitions as a mean for collaboration on the other axis. Basically, pharmaceutical companies can choose between other pharmaceutical partners, on the one hand, and biotechnology companies, on the other hand, in order to realize their innovation strategy. Moreover, this study design makes a distinction between two different collaborative strategies. First, strategic alliances comprise any kind of partnership such as licensing or R\&D agreements, through which the company can gain access to the required knowledge. Strategic alliances - based on the commitment of two or more partner firms - can be considered as a fast and flexible way to get access to complementary resources and skills residing in other companies [5,6]. Second, M\&A is considered as a powerful mean in order to integrate companies which possess the necessary knowledge and capabilities [7,8].

Throughout the last decade, many pharmaceutical companies felt the pressure from slowing sales, the looming expiration of patent protection and eroding profit margins. e.g., in early December 2001, Merck \& Co. announced that its earning would be flat in 2002 and Bristol-Myers Squibb predicted that its 2002 earnings will be below 2001 levels.

Moreover, an increasing number of strategic alliances as well as further M\&A activities could be observed. E.g.:

- Bristol-Myers Squibb Co. promised \$2 billion to ImClone Systems Inc. for an equity stake in the New York firm and the co-commercialization rights to its anti-cancer therapeutic.

- CuraGen Corp. signed a \$1.34 billion deal with Bayer for the discovery and development of small molecule drugs for treating obesity and diabetes.

- PerkinElmer completed the acquisition of Packard BioScience in a deal worth $\$ 650$ million.

- Merck acquired Rosetta Impharmatics for \$540 million.

These few examples show that both strategies, strategic alliances and M\&A, are considered as a useful mean in order to support the innovative engine of pharmaceutical companies [3]. In fact there is a continuous increase in the number of alliances as well as M\&A activities between pharmaceutical and biotechnology companies [1]. Besides this, there has also been an increase in collaborative and M\&A activities

*Corresponding author: Lars Schweizer, Goethe University Frankfurt, UBSEndowed Chair for Strategic Management, Grueneburgplatz 1, 60322 Frankfurt am Main, Germany, Tel: 496979834 832; Fax: 496979835 020, E-mail: I.schweizer@em.uni-frankfurt.de

Receved January 15, 2014; Accepted July 24, 2014; Published August 01, 2014

Citation: Schweizer L (2014) Strategic Alliances or M \& A as the Road to Innovation for Pharmaceutical Companies? J Entrepren Organiz Manag 3: 116. doi: 10.4172/2169-026X.1000116

Copyright: () 2014 Schweizer L. This is an open-access article distributed under the terms of the Creative Commons Attribution License, which permits unrestricted use, distribution, and reproduction in any medium, provided the original author and source are credited. 
Citation: Schweizer L (2014) Strategic Alliances or M \& A as the Road to Innovation for Pharmaceutical Companies? J Entrepren Organiz Manag 3: 116. doi: 10.4172/2169-026X.1000116

Page 2 of 2

between pharmaceutical companies themselves. However, it remains unclear under what conditions pharmaceutical companies engage in collaborations or M\&A with other pharmaceutical companies or with biotechnology companies in order to support their innovation strategy.

Outlook: Research questions and research methodology:

Future research should try to provide some insights in order to answer the following questions:

- How are strategies shaped within the pharmaceutical company and who is involved in the strategic decision-making process?

- Is there a certain development path from one innovation (collaboration) strategy to another?

- What factors do influence the decision to use alliances instead of acquisitions in order to realize the best innovation strategy?

- What role does the location of the potential partner play when deciding about the appropriate innovation strategy?

Such a study does not only ask 'what' questions, it also asks 'why' and 'how' questions. The appropriate research methodology for a study that attempts to extend theory by description and analysis is the comparative case study research methodology [9-11]. Thus, based on a semi-structured questionnaire interviews should be carried out with executives from different pharmaceutical and biotechnology firms, such as e.g. Novartis, Bayer, Genentech, or Merck. Moreover, secondary data such as analysts' reports, press articles as well as annual reports should be included in order to answer these research questions.

\section{References}

1. Patzelt H, Schweizer L, Behrens J (2012) Biotechnology Entrepreneurship, in Foundations and Trends in Entrepreneurship 8: 63-140.

2. Sachs G (2001) Strategic alliances in biotechnology, Eight Edition. New York Author.

3. Al-Laham A, Schweizer L, Amburgey TL (2010) Dating before marriage? Analyzing the influence of acquisition experience, direct alliance experience and sector familiarity on acquisition success in the "M\&A as R\&D" type of acquisition. Scandinavian Journal of Management 26: 25-37.

4. Powell W (1998) Learning from collaboration. Knowledge and networks in the biotechnology and pharmaceutical industries. California Management Review 40: $228-240$.

5. Dyer JH, Kale P, Singh H (2001) How to make strategic alliances work. Sloan Management Review 42: 37-43.

6. Jorde TM, Teece DJ (1989) Competition and cooperation: Striking the right balance. California Management Review 31: 25-37.

7. Schweizer L (2005) Organizational integration of acquired biotechnology companies in pharmaceutical companies: The need for a hybrid strategy. Academy of Management Journal 48: 1051-1074.

8. Schweizer L (2009) Post-merger integration of international biotechnology start-ups - The relationship between entrepreneurial strategy, culture and human resources. Journal of Business Economics, Special Issue International Entrepreneurship 61: 133-153.

9. Eisenhardt K (1989) Building theories from case study research. Academy of Management Review 14: 532-550.

10. Yin RK (1984) Case study research: Design and methods. Applied social research methods series 5, Beverly Hills: Sage.

11. Glaser B, Strauss AL (1967) The discovery of grounded theory. Strategies of qualitative research, London: Wiedenfeld and Nicholson. 